\title{
Detection of the Panton-Valentine Leukocidin Gene in Swedish Isolates of Methicillin-Resistant Staphylococcus aureus using a Multiplex PCR Assay
}

\author{
Waleed Abu Al-Soud ${ }^{1,2}$ \\ ${ }^{1}$ Clinical Microbiology, Lund University Hospital, Lund, Sweden; ${ }^{2}$ Clinical Laboratory Sciences, Applied Medical Sciences, Jouf \\ University, Qurayyat, Kingdom of Saudi Arabia
}

\begin{abstract}
Background: Panton-Valentine leukocidin (PVL) is a bicomponent leukotoxin produced by $<2 \%$ of Staphylococcus aureus (S. aureus) strains. PVL forms transmembrane pores that cause cell disruption and death. PVL is associated with skin necrotic lesions and severe necrotizing pneumonia. The methicillin-resistant $S$. aureus (MRSA) strains that harbor the lukS-PV gene (the gene encoding PVL toxin) are considered highly pathogenic since they can cause infections that are difficult to treat.

Objective: This study aimed to optimize a multiplex PCR assay that can detect both methicillin-resistant $S$. aureus strains and their ability to produce PVL toxin isolated from Swedish patients.

Methods: An optimized multiplex PCR-assay was developed to detect both nuc and lukS-PV genes and was applied to a collection of 80 MRSA clinical isolates collected between 1999 and 2004.

Results: The results showed that 30/80 (40\%) of all MRSA isolates were PVL-positive. The highest PVL prevalence (86\%) was among abscess isolates. When PVL was correlated to staphylococcal protein A (spa) typing, the highest PVL positivity was among spa-type 44.

Conclusion: The results of this study showed that the lukS-PV gene is common among Swedish community of the MRSA isolates.

Keywords: Leukotoxin; Panton-Valentine leukocidin; Methicillin-resistant Staphylococcus aureus nuclease gene; Staphylococcal protein A
\end{abstract}

\section{INTRODUCTION}

Staphylococcus aureus (S. aureus) is a Gram-positive, catalase and coagulase positive coccus bacterium, that grows single, diplo, tetrads and irregular clusters (grape-like) [1]. S. aureus is a major cause of nosocomial infections due to its ability to produce many virulence factors and to develop multiple drug resistance $[2,3]$. Almost all S. aureus strains can secrete a group of enzymes and toxins which include nucleases, proteases, lipases, hyaluronidase, and collagenase, which help the bacteria to spread into human tissue and convert host tissues into nutrients necessary for bacterial survival and growth [4]. All S. aureus strains also produce an extracellular thermostable nuclease (thermonuclease, TNase) which is an endonuclease $(\mathrm{MW}=17 \mathrm{kDa})$, which degrades both DNA and RNA [5]. This nuclease is encoded by the nuc gene and may be used to distinguish between $S$. aureus from coagulase-negative Staphylococci [6]. The Staphylococcal proteinA (encoded by the spa-gene) is an extracellular protein that binds to the fragment crystallizable $(\mathrm{Fc})$ region of Immunoglobulin $\mathrm{G}$ (IgG) inhibiting the host immune response by disrupting cell opsonization and phagocytosis [7].

Several leukotoxins such as Pantone Valentine (PVL) and $\gamma$ Haemolysin (HIg) are produced by S. aureus [8,9]. PVL is produced by only $2 \%$ of S. aureus strains, but HIg is produced by almost all the strains [9]. The PVL has been detected in S. aureus strains isolated from human patients with abscesses, furuncles, and in community-acquired severe necrotic pneumonia $[10,11]$. PVL causes leukocytosis and tissue necrosis by means of pore formation on the target cells, and its toxicity involves two

${ }^{*}$ Correspondence to: Waleed Abu Al-Soud, Assistant Professor, Al-Jouf University College of Applied Medical Sciences, Clinical Laboratory Sciences, Umar Ibn Abdulaziz, At Tahliyyah Qurayyat, 75911, Kingdom of Saudi Arabia, Tel: 0046735991700; E-mail: w.abualsoud@gmail.com

Received: March 19, 2019; Accepted: April 2, 2019; Published: April 8, 2019

Citation: Al-Soud W (2019) Detection of the Panton-Valentine Leukocidin Gene in Swedish Isolates of Methicillin-Resistant Staphylococcus aureus using a Multiplex PCR Assay. J Bacteriol Parasitol 10:353. doi: 10.4172/2155-9597.1000353

Copyright: ( 2019 Al-Soud WA, et al. This is an open-access article distributed under the terms of the Creative Commons Attribution License, which permits unrestricted use, distribution, and reproduction in any medium, provided the original author and source are credited. 
soluble, non-associated but synergic exoproteins a slow-eluting from the ion exchange column (class $S$ protein) and a fasteluting from the ion exchange column (class F protein) [12]. The synergistic action of 2 secretory proteins form pores in the membrane of host defense cells and are encoded by 2 cotranscribed genes (LukS-PV and LukF-PV) on a prophage integrated into the $S$. aureus chromosome [13]. The $S$ class proteins include $\mathrm{HIgA}, \mathrm{HIgC}$ and LukS-PV, whereas proteins of the F class include HIgB, LukF-PV, and LukM. The PVL activity starts with binding of the LukS-PVL (MW=32 kDa) component to certain host membrane receptors on polymorphonuclear (PMN) leukocytes and monocytes, which allows binding of the second component LukF-PVL [2,14]. Binding of the Luk-F $(\mathrm{MW}=34 \mathrm{kD} 3)$ leads to the formation of oligomeric transmembrane channels specific for the traffic of monovalent cations; these sequential interactions at the membrane surface induce opening of $\mathrm{Ca}^{2+}$ channels and increase the free intracellular $\mathrm{Ca}^{2+}$ concentration [15]. Apoptosis was only triggered at low PVL concentrations, whereas higher concentrations induced necrotic alterations [16]. The activation of the PMN leukocytes induces granule secretion in the PMN leukocytes and the release of inflammatory mediators (leucotriene B4, interleukin-8, interleukin-6, and interleukin-12) which are involved in chemotactic and vasodilatation [17].

The $\beta$-lactam antibiotics such as Benzylpenicillin (penicillin G) were used successfully to treat $S$. aureus infections, but by the late 1950s, an increasing rate of $S$. aureus strains resistant to benzylpenicillin was a cause for concern [1]. Strains resistant to penicillin $G$ produce a $\beta$-lactamase enzyme, which inactivates the $\beta$-lactam-ring of the antibiotics. At the beginning of the 1960s methicillin was introduced, a penicillin derivative that was resistant to $\beta$-lactam hydrolysis [18]. Unfortunately, as soon as methicillin was introduced clinically, the first isolates of methicillin-resistant S. aureus (MRSA) were reported in 1960 [19]. The resistance to methicillin is induced by the presence of penicillin-binding protein (PBP 2a), which is encoded by the mecA gene and has a low binding affinity to $\beta$-lactam antibiotics, and substitute the native PBPs and thereby allow a continuous cell assembly [20].

Like other S. aureus, MRSA can colonize the skin and body of an individual without causing sickness (carriers), and in this way, it can be passed on to other susceptible individuals unknowingly [21]. Problems arise in the treatment of overt infections with MRSA because the antibiotic choice is very limited although treatment with vancomycin so far remains an acceptable treatment option [22].

In Sweden, the Swedish Institute for Infectious Disease Control (SMI) has reported 3375 cases of human MRSA in 2017 [23].

There are increasing reports of MRSA harboring the PVL toxin, which increases strains pathogenicity and their ability to cause infections that are difficult to treat.

Therefore, this study aimed to optimize a simple and rapid multiplex PCR assay for simultaneous detection of lukS-PV, and nuc genes and investigate the prevalence of PVL positive Swedish MRSA clinical isolates.

\section{MATERIALS AND METHODS}

\section{Bacterial isolates and DNA extraction}

The MRSA strains culture collection included in this study (80 strains) were collected at the clinical microbiology and immunology laboratory at Lund University Hospital, Sweden. The strains were isolated from the throat (9), wound (20), perineum (2), abscesses (7), respiratory tract (29), and unknown sites (13). Samples were cultivated on two culture media: a halfblood agar plate with aztreonam disc and on a half selective oxacillin plate with oxacillin disc and incubated aerobically overnight at $37^{\circ} \mathrm{C}$. The rest of the sample was suspended in a tryptic-soy broth (TSB) containing $72.0 \mu \mathrm{g} / \mathrm{ml}$ colistin and 0.05 $\mu \mathrm{g} / \mathrm{ml}$ penicillin $\mathrm{V}(\mathrm{PcV})$ and cultivated on the other halves of the two agar plates. The isolates were characterized as $S$. aureus based on colony morphology, coagulase- and agglutination-test with Pastorex Staph Plus (bioMérieux, France). Resistance to oxacillin (MIC>I mg/L) was determined by using disc diffusion tests according to the Swedish Reference Group for Antibiotics (SRGA, www srga.org). The presence of the mecA gene in the suspected MRSA strains was confirmed by PCR assay. The positive-MRSA strains were preserved in calf serum media at $-80^{\circ} \mathrm{C}$. The MRSA-strain (SMI 04-1) was used as positive control for the lukS-PV gene, whereas sterile Millipore water was added to negative controls.

For molecular testing, clinical strains were thawed and recultivated on blood agar plates overnight at $37^{\circ} \mathrm{C}$. A ten-fold dilution series (102 to $108 \mathrm{CFU} / \mathrm{ml})$ in sterilized water were prepared. The diluted bacteria were heated at $95^{\circ} \mathrm{C}$ for $15 \mathrm{~min}$ in a thermocycler (Applied Biosystems, PCR system 2700) to lyse bacterial cells and free the DNA.

\section{PCR primers and amplification conditions}

Detection of the lukS-PV gene was done using previously published primers [11], PVL-f and PVL-r, which were ordered from SyberGene AB (Stockholm, Sweden). The PCR mixture $(50 \mu \mathrm{l})$ containing 1X PCR buffer, $3.0 \mathrm{mM} \mathrm{MgCl}_{2}, 0.6 \mu \mathrm{M}$ of each primer (PVL-F and PVL-R), $200 \mu \mathrm{M}$ of each dATP, dCTP and dGTP, $300 \mu \mathrm{M}$ dUTP and $1 \mathrm{U}$ of Taq DNA polymerase (HotStar Taq, VWR International, Stockholm, Sweden). Exactly $5 \mu \mathrm{l}$ of DNA extracted by heating the suspension was added to the reaction mixture. PCR mixtures were incubated at $95^{\circ} \mathrm{C}$ for $15 \mathrm{~min}$ (Hot Start) followed by 40 cycles of denaturation at $93^{\circ} \mathrm{C}$ for $50 \mathrm{~s}$, annealing at $53^{\circ} \mathrm{C}$ for $50 \mathrm{~s}$, and extension at $72^{\circ} \mathrm{C}$ for $50 \mathrm{~s}$ followed by final extension at $72^{\circ} \mathrm{C}$ for $8 \mathrm{~min}$. A $14 \mu \mathrm{l}$ PCR product was analyzed on $2 \%$ agarose gel electrophoresis in $1 X$ Tris-Acetate-EDTA (TAE)-buffer $(40 \mathrm{mM}$ Tris-HCI-20 mM EDTA, pH 8.0) and stained with $0.5 \mu \mathrm{M}$ Ethidium bromide. Estimation of the PCR product size was done by using a fragment standard (Gen Ruler 100 bp DNA ladder, MBI Fermentas, Vilnius, Lithuania). The gels were run in 1 XTAEbuffer at $130 \mathrm{~V}$ for $30 \mathrm{~min}$. The PCR products were visualized using a GelDoc 2000 UV-camera (BIORAD, Hercules, CA, USA). 


\section{Multiplex-PCR assay (lukS-PV and nuc genes)}

A multiplex PCR-based assay was developed for detection of both lukS-PV and nuc genes by using $0.6 \mu \mathrm{M}$ of each lukS-PV specific primers (PVL-f, and PVL-r), $0.1 \mu \mathrm{M}$ of each nuc-specific primers [6], nuc-forward (N1), and nuc-reverse (N2) ordered from SyberGene AB (Stockholm, Sweden; Table 1). The PCR mixture $(50 \mu \mathrm{l})$ contained $1 \mathrm{X}$ PCR buffer, $3.0 \mathrm{mM} \mathrm{MgCl}, 200 \mu \mathrm{M}$ of each dATP, dCTP and dGTP, $300 \mu \mathrm{M}$ dUTP, and 1U of Taq DNA-polymerase. Exactly $5 \mu \mathrm{l}$ of DNA extracted by heating was added to the reaction mixture. The MRSA strain CCUG 35602 was used as a positive control for the nuc gene. DNA amplification conditions were the same as the lukS-PV PCR assay mentioned above.

Table 1: Oligonucleotide primers used in the multiplex PCR assay.

\begin{tabular}{|c|c|c|c|}
\hline Oligonucleotide & nucleotide sequence & PCR product & $\operatorname{Tm}^{1}$ \\
\hline \multicolumn{4}{|c|}{ A) lukS-PV specific primers } \\
\hline PVL-f (forward) & 5'-GTAAAATGTCTGGACATGATCCAY-3' & $433 \mathrm{bp}$ & $58^{\circ} \mathrm{C}$ \\
\hline PVL-r (reverse) & 5'-GCATCAASTGTATTGGATAGCA-3' & & \\
\hline \multicolumn{4}{|c|}{ B) nuc-specific primers } \\
\hline N1 (forward) & 5'-GCGATTGATGGTGATACGGTT-3' & $279 \mathrm{bp}$ & $58^{\circ} \mathrm{C}$ \\
\hline N2 (reverse) & 5'-CAAGCCTTGACGAACTAAAGC -3' & & \\
\hline
\end{tabular}

\footnotetext{
${ }^{1}$ Tm: Melting Temperature

2PVL: Panton Valentin Leukocidin

${ }^{3}$ nuc: Thermostable Nuclease Gene
}

\section{RESULTS}

\section{Optimizing of lukS-PVPCR assay}

The effect of changing the annealing temperature and primer concentration on the detection limit of PVL PCR assay was evaluated by testing different annealing temperature $\left(55^{\circ} \mathrm{C}\right.$ and $\mathrm{S} 3^{\circ} \mathrm{C}$ ) on the ability of Taq DNA polymerase to amplify lukS-PV gene. When a high annealing temperature $\left(55^{\circ} \mathrm{C}\right)$ was used the minimum concentration of S. aureus detected was $10^{5} \mathrm{CFU} / \mathrm{ml}$. Reducing the annealing temperature to $53^{\circ} \mathrm{C}$ lowered the detection limit and allowed detection of $10^{4} \mathrm{CFU} / \mathrm{ml}$. When we studied the effect of lukS-PV Primer concentration, it was found that the best Primer concentration among those tested was 0.6 $\mu \mathrm{M}$ which allowed detection of $10^{4} \mathrm{CFU} / \mathrm{ml}$. By changing the cycle number from 30 to 40 cycles did not affect the PCR detection limit. The PCR product appears as a single band with a size of $433 \mathrm{bp}$. The repeating of the testing with other S. aureus strains gave the same results.

\section{Optimizing of the multiplex-PCR assay (lukS-PV and nuc-genes)}

The developed multiplex PCR-assay for detection of both the lukS-PV, and the nuc genes based on already published primers [6,11], the nuc primers are used for the routine diagnosis of MRSA strains in the Medical Microbiology and Immunology Laboratory, Lund University Hospital, Lund, Sweden. The selection of the lukS-PV and nuc specific primers was based on their specificity to the target genes. Both primer sets had almost equal annealing temperatures, and they have different size of amplified PCR products (433 bp for lukS-PV gene and $270 \mathrm{bp}$ for the nuc gene; Figure 1). The PCR conditions used for the multiplex PCR assay were the same as those mentioned above and allowed amplification of both genes with a detection limit of $10^{4} \mathrm{CFU} / \mathrm{ml}$.

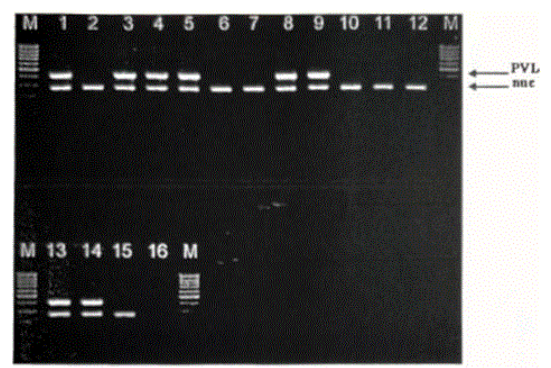

Figure 1: Detection of lukS-PV and nuc genes in Swedish MRSA clinical strains using a multiplex PCR assay. Lanes: M, DNA ladder (Gen Ruler 100 bp DNA ladder, MBI Fermentas, Vilnius, Lithuania); 1, PVL-gene positive control (SMI 04-1); 16, negative control (sterile water); 2-15, MRSA clinical isolates.

\section{Prevalence of the lukS-PV and nuc genes among MRSA clinical isolates}

All the 80-MRSA isolates collected between 1999 and 2004 were positive for nuc gene. When lukS-PV PCR assay was applied to these isolates, it was found that 30/80 (40\%) were PVL-positive 
by amplification of the $433 \mathrm{bp}$ specific PCR product (Table 2). The distribution of PVL positive isolates among the different MRSA isolates were: $11 / 20(50 \%)$ of wounds, $6 / 7(86 \%)$ of abscesses, 9/29 (30\%) of respiratory tract infections, 1/9 (11\%) of throat, and $2 / 13$ (23\%) from unknown sites. All the 80 samples were positive for the nuc gene PCR assay by amplification of the 279-bp specific PCR product.

Table 2: Prevalence of the lukS-PV gene in clinical MRSA strains as established using the PCR-based assay.

\begin{tabular}{lll}
\hline Sample type & No. & Positive No. (\%) \\
\hline Throat & 9 & $1(11)$ \\
\hline Wound & 20 & $11(50)$ \\
\hline Abscess & 7 & $6(86)$ \\
\hline
\end{tabular}

\begin{tabular}{lcc}
\hline Respiratory tract infections & 29 & $9(31)$ \\
\hline Perineal secret & 2 & $0(0)$ \\
\hline Others & 13 & $3(23)$ \\
\hline Total & 80 & $30(40)$ \\
\hline
\end{tabular}

The spa-typing of MRSA strains uses the sequence of a polymorphic variable number tandem repeat (VNTR) in the $3^{\prime}$ coding region of the $S$. aureus -specific staphylococcal protein A (spa) [24]. The correlation between the spa-typing of MRSA strains included in this study and PVL-results was investigated (Table 3). It was found that the spa type 44 (UIGBBPB) was the most common type with (95\%) frequency. All the isolates with spa types 08 (YHGFMBQBLO) and spa type 131 (UIGBPB) were PVL positive.

Table 3: Correlation between spa-typing and PVL-positive MRSA strains.

\begin{tabular}{|c|c|c|c|}
\hline Spa-Typing1 & Spa-pattern2 & No. & Positive No. (\%) \\
\hline 1 & TIMBMDMGMK & 2 & $0(0)$ \\
\hline 2 & TJMBMDMGMK & 14 & $1(7)$ \\
\hline 8 & YHGFMBQBLO & 3 & $3(100)$ \\
\hline 10 & TMBMDMGMK & 1 & $0(0)$ \\
\hline 15 & ХКАКВЕМВКВ & 3 & $0(0)$ \\
\hline 18 & WGKAKAOMQQQ & 4 & $0(0)$ \\
\hline 19 & XKAKAOMQ & 1 & $1(100)$ \\
\hline 30 & WGKAQQ & 2 & $0(0)$ \\
\hline 32 & TJJEJNJ2MNJ2MOMOKR & 2 & $0(0)$ \\
\hline 37 & WGKAOMQ & 2 & $0(0)$ \\
\hline 41 & TMBMDMBMDMGMK & 3 & $0(0)$ \\
\hline 44 & UJGBBPB & 19 & $18(95)$ \\
\hline 67 & TJMBMDMGM & 3 & $0(0)$ \\
\hline 127 & UJFKBPE & 1 & $1(100)$ \\
\hline 131 & UJGBPB & 2 & $2(100)$ \\
\hline 148 & UJGFGMDMGGM & 1 & $0(0)$ \\
\hline 230 & XKAKB & 1 & $0(0)$ \\
\hline 286 & UJEBKBPE & 5 & $0(0)$ \\
\hline 296 & XКАОВ3В3В3 & 1 & $0(0)$ \\
\hline
\end{tabular}




\begin{tabular}{lll}
\hline Unknown & 10 & $4(40)$ \\
\hline Total & 80 & $30(40)$ \\
\hline
\end{tabular}

Spa typing was done as previously described by Shopsin et al. Repeat codes are derived from the organization of individual repeats (random alphabetical code). There are 13 distinct repeat types.

\section{DISCUSSION}

DNA amplification by PCR has been applied successfully in the diagnosis of infectious diseases. It offers advantages, such as speed, specificity, and sensitivity [25]. The PVL PCR assay used in this study was found to be specific for the lukS-PV gene based on analysis of reference DNA sequences of two S. aureus strains, (SMI 04-1, and ATCC 27733), and allowed amplification of 433 bp of lukS-PV gene-specific PCR product. The detection limit of the PVL PCR assay was $10^{4} \mathrm{CFU} / \mathrm{ml}$ of boiled S. aureus cells suspension, which was close to the theoretical detection limit of PCR $\left(10^{3} \mathrm{CFU} / \mathrm{ml}\right)$. Although lysis of bacterial cells by boiling is a simple, inexpensive, time saving and reduces the risk of contamination between samples, on the other hand, the thick cell wall of $S$. aureus requires boiling cells for a long time, which increases the possibility of DNA degradation and reducing the sensitivity of PCR [12]. Despite the drawbacks of boiling, we decided to use it because we applied the PVL PCR assay on pure cultures that have bacterial cell number concentration above the PCR assay detection limit which was $10^{4} \mathrm{CFU} / \mathrm{ml}$. Taq DNA polymerase "Hot start," which was activated at a higher temperature, was used to avoid amplification of unspecific PCR products due to non-specific annealing and primer elongation.

The combination of the production of PVL, which is a potent toxin involved in severe skin infections and necrotizing pneumonia, with resistance to commonly used antibiotics and ability to spread easily in certain communities, possess a potential threat to public health. Outbreaks of PVL-producing strains have recently been reported worldwide [26]. PVLproducing strains have been identified in the US. The PVL producing S. aureus stains belong to the USA300 genotype and are associated Skin and soft-tissue infections, necrotizing pneumonia, and sepsis and have been found to colonize healthy children and children with cancer [27]. Similarly, PVLproducing strains have been identified in the gay community in the Netherlands, which was found in $10 \%$ of the MRSA isolates [28]. An outbreak of PVL producing strains among healthy French teenagers was also reported [29].

There is an increasing concern of the outbreaks of S. aureus PVL-producing strains, which are associated with rapidly progressive, hemorrhagic, necrotizing, community-acquired pneumonia in young immunocompetent patients with high fatality rate [30]. Familial carriage of S. aureus PVL-producing strains has been shown to be a risk factor for subsequent infection with the same strain in neonates [31].

The results of this study showed that the lukS-PV gene was prevalent in the Swedish MRSA strain community (40\%), which is higher than the 5\% PVL reported in Western Europe [9]. The highest prevalence of PVL-positive strains was found among strains had been associated with furuncles which appear as a central area of subcutaneous necrosis due to direct activation and lysis of PMN by the PVL toxin [11]. In this study, the highest prevalence of MRSA PVL positive strains had been isolated from abscesses (86\%), skin wounds (50\%), and respiratory tract infections (30\%), whereas only $11 \%$ of isolates collected from throat were PVL-positive. These results are in accordance with results reported by Lina et al. [11] who found that the PVL detected in $50 \%$ of S. aureus were isolated from the cutaneous abscess, cellulite, or furunculosis. This was also confirmed by Couppie et al. [32,33] who detected PVL in $86 \%$ of abscesses. Some of the abscesses could have originated from true furuncles that faced destruction by the necrotic process and appeared as skin abscesses. In contrast, superficial, nonnecrotic processes such as impetigo and folliculitis were not associated with PVL-harboring S. aureus .

When we investigated the correlation between the spa-typing (which was done before) and PVL- results, it was found that the spa type-44 was the most common type with (95\%) frequency. We had only 3 isolates with spa-type 0 and two spa-type 131, all of them were PVL positive. Unfortunately, we did not have enough samples to compare the prevalence of PVL positive samples with the other spa types. However, it will be interesting to collect more samples and to test the correlation between these two virulence factors.

\section{CONCLUSIONS}

PVL appears to be a possible virulence factor associated with specific cases such as necrotic lesions of the skin, and subcutaneous tissues and community-acquired severe necrotic pneumonia. Association of lukS-PV gene as a virulence factor and mecA gene as a resistance factor makes S. aureus a welladapted pathogen. Problems arise in the treatment of infections with MRSA because the use of different types of antibiotic over the years has led to the emergence of multiple drug resistant MRSA, which makes the therapeutic choice very limited. Further studies will be performed in order to gain more insight into the microbiological and epidemiological background of these virulent MRSA strains. lukS-PV gene could be successfully detected by the PCR assay employed here and allowed simultaneous detection of PVL producing MRSA strains.

\section{REFERENCES}

1. Stapleton PD, Taylor PW. Methicillin resistance in Staphylococcus aureus : mechanisms and modulation. Sci Prog 2002;85(1):57-72.

2. König B, Prévost G, Piémont Y, Konig W. Effects of Staphylococcus aureus leukocidins on inflammatory mediator release from human granulocytes. J Infect Dis 1995;171(3):607-613. 
3. Prevost G, Mourey L, Colin DA, Menestrina G. Staphylococcal pore-forming toxins. Curr Top Microbiol Immunol 2001;257:53-83.

4. Oliveira D, Borges A, Simoes M. Staphylococcus aureus toxins and their molecular activity in infectious diseases. Toxins 2018;10(6): 1-19.

5. Tucker PW, Hazen EE Jr, Cotton FA. Staphylococcal nuclease reviewed: a prototypic study in contemporary enzymology. I. Isolation; physical and enzymatic properties. Mol Cell Biochem 1978;22(2-3):67-77.

6. Brakstad OG, Aasbakk K, Maeland JA. Detection of Staphylococcus aureus by polymerase chain reaction amplification of the nuc gene. J Clin Microbiol 1992;30(7):1654-1660.

7. Votintseva AA, Fung R, Miller RR, Knox K, Godwin H, Wyllie $\mathrm{DH}$, et al. Prevalence of Staphylococcus aureus protein A (spa) mutants in the community and hospitals in Oxfordshire. BMC Microbiol 2014;14:1-11.

8. Spaan AN, Vrieling M, Wallet P, Badiou C, Reyes-Robles T, Ohneck EA, et al. The staphylococcal toxins gamma-haemolysin $\mathrm{AB}$ and $\mathrm{CB}$ differentially target phagocytes by employing specific chemokine receptors. Nat Commun 2014;5:1-11.

9. Prévost G, Cribier B, Couppié P, Petiau P, Supersac G, FinckBarbançon V, et al. Panton-Valentine leucocidin and gammahemolysin from Staphylococcus aureus ATCC 49775 are encoded by distinct genetic loci and have different biological activities. Infect Immun 1995;63(10):4121-4129.

10. Cribier B, Prévost G, Couppie P, Finck-Barbançon V, Grosshans E, Piémont Y. Staphylococcus aureus leukocidin: a new virulence factor in cutaneous infections? An epidemiological and experimental study. Dermatol 1992;185(3):175-180.

11. Lina G, Piémont $\mathrm{Y}$, Godail-Gamot F, Bes M, Peter MO, Gauduchon V, et al. Involvement of panton-valentine leukocidinproducing Staphylococcus aureus in primary skin infections and pneumonia. Clin Infect Dis 1999;29(5):1128-1132.

12. Finck-Barbançon V, Duportail G, Meunier O, Colin DA. Pore formation by a two-component leukocidin from Staphylococcus aureus within the membrane of human polymorphonuclear leukocytes. Biochim Biophys Acta 1993;1182(3):275-782.

13. Melles DC, van Leeuwen WB, Boelens HAM, Peeters JK, Verbrugh HA, Belkum AV. Panton-Valentine leukocidin genes in Staphylococcus aureus . Emerg Infect Dis 2006;12(7):1174-1175.

14. Colin DA, Mazurier I, Sire S, Finck-Barbançon V. Interaction of the two components of leukocidin from Staphylococcus aureus with human polymorphonuclear leukocyte membranes: sequential binding and subsequent activation. Infect Immun 1994;62(8): 3184-3188.

15. Staali L, Monteil H, Colin DA. The staphylococcal pore-forming leukotoxins open $\mathrm{Ca} 2+$ channels in the membrane of human polymorphonuclear neutrophils. J Membr Biol 1998;162(3): 209-216.

16. Genestier AL, Michallet MC, Prévost G, Bellot G, Chalabreysse L, Peyrol S, et al. Staphylococcus aureus Panton-Valentine leukocidin directly targets mitochondria and induces Bax-independent apoptosis of human neutrophils. J Clin Invest 2005;115(11): 3117-3127.

17. Baba-Moussa L, Sina H, Scheftel JM, Moreau B, Sainte-Marie D, Kotchoni, SO. Staphylococcal Panton-Valentine leucocidin as a major virulence factor associated to furuncles. PLoS One 2011;6:e25716.

18. Voss A, Doebbeling BN. The worldwide prevalence of methicillinresistant Staphylococcus aureus. Int J Antimicrob Agents 5(2): 101-106.
19. Chambers HF (1997) Methicillin resistance in staphylococci: molecular and biochemical basis and clinical implications. Clin Microbiol Rev 1995;10(4):781-791.

20. Fishovitz J, Hermoso JA, Chang M, Mobashery S. Penicillinbinding protein 2a of methicillin-resistant Staphylococcus aureus . IUBMB Life 2014;66(8):572-577.

21. Bradley SF. MRSA colonisation (eradicating colonisation in people without active invasive infection). BMJ Clin Evid 2015;11:1-8.

22. Choo EJ, Chambers HF. Treatment of Methicillin-Resistant Staphylococcus Aureus Bacteremia. Infect Chemother 2016;48(4): 267-273.

23. Anonymous. A report on Swedish antibiotic utilisation and resistance in human medicine (Swedres) and Swedish veterinary antibiotic resistance monitoring (Svarm) in Erika Olsson and Olov Aspevall, et al. (eds), 2017; Swedres Svarm (Solna, Sweden: The Public Health Agency of Sweden).

24. Harmsen D, Claus H, Witte W, Rothgänger J, Claus H, Turnwald D, et al. Typing of methicillin-resistant Staphylococcus aureus in a university hospital setting by using novel software for spa repeat determination and database management. J Clin Microbiol 2003;41(12):5442-5448.

25. Lantz PG, Abu al-Soud W, Knutsson R, Hahn-Hägerdal B, Rådström P. Biotechnical use of polymerase chain reaction for microbiological analysis of biological samples. Biotechnol Annu Rev 2000;5:87-130.

26. Pei S, Morone F, Liljeros F, Makse H, Shahman JL. Inference and control of the nosocomial transmission of methicillin-resistant Staphylococcus aureus . Elife 2018;7:1-25.

27. Srinivasan A, Seifried SE, Zhu L, Srivastava DK, Perkins R, Shenep JL, et al. Increasing prevalence of nasal and rectal colonization with methicillin-resistant Staphylococcus aureus in children with cancer. Pediatr Blood Cancer 2010;55(7):1317-1322.

28. Wannet WJB. Virulent MRSA strains containing the Panton Valentine leukocidin gene in the Netherlands.Weeklyreleases 2003; 7:2173.

29. Dufour P, Gillet Y, Bes M, Lina G, Vandenesch F, Floret D, et al. Community-acquired methicillin-resistant Staphylococcus aureus infections in France: emergence of a single clone that produces Panton-Valentine leukocidin. Clin Infect Dis 2002;35(7):819-824.

30. Gillet Y, Issartel B, Vanhems P, Fournet JC, Lina G, Bes M, et al. Association between Staphylococcus aureus strains carrying gene for Panton-Valentine leukocidin and highly lethal necrotising pneumonia in young immunocompetent patients. Lancet 2002;359(9308): 753-759.

31. Hollis RJ, Barr JL, Doebbeling BN, Pfaller MA, Wenzel RP. Familial carriage of methicillin-resistant Staphylococcus aureus and subsequent infection in a premature neonate. Clin Infect Dis 1995;21(2):328-332.

32. Couppié P, Hommel D, Prévost G, Godart MC, Moreau B, SainteMarie D, et al. Staphylococcus aureus septicemia producing PantonValentine leukocidin. 3 cases. Annals of Dermatology and Venereology 1997;124:684-686.

33. Shopsin B, Gomez M, Montgomery SO, Smith DH, Waddington $\mathrm{M}$, Dodge DE, et al. Evaluation of protein A gene polymorphic region DNA sequencing for typing of Staphylococcus aureus strains. J Clin microbial 1999;37(11):3556-3563. 